Dorota Grabowska-Pieńkosz

ORCID: 0000-0003-1704-626X

Uniwersytet Mikołaja Kopernika w Toruniu

Joanna Falkowska ORCID: 0000-0002-6895-3014 Uniwersytet Mikołaja Kopernika w Toruniu

\title{
Współczesne tendencje w nauczaniu historii wychowania w wybranych ośrodkach akademickich
}

\section{Modern Trends in the Teaching of the History of Education in Selected Academic Institutions}

\begin{abstract}
ABSTRAKT
Jednym z przedmiotów kształcenia przyszłych pedagogów jest historia wychowania. W ramach realizacji zajęć przekazywane sq studentom zagadnienia z zakresu polskiej i powszechnej historii wychowania, a mianowicie praktyki pedagogicznej i historii myśli pedagogicznej. Uwzględniany jest nie tylko dorobek pedagogiki ogólnej i jej subdyscyplin, ale także, ze względu na interdyscyplinarny charakter pedagogiki, bardzo ważny dorobek filozofii, socjologii czy psychologii.

W artykule zaprezentowano współczesne tendencje w nauczaniu historii wychowania w wybranych ośrodkach akademickich. Autorki zaprezentowały refleksie nad znaczeniem historii wychowania jako przedmiotu nauczania na studiach pedagogicznych. Na podstawie uzyskanych wyników analiz sylabusów (programów nauczania)
\end{abstract}

SLOWA KLUCZOWE historia wychowania, studia wyższe, kształcenie akademickie, współczesne tendencje, programy nauczania

KEYWORDS

history of education, higher education, academic education, contemporary trends, curricula

SPI Vol. 23, 2020/2

ISSN 2450-5358

e-ISSN 2450-5366 DOI: 10.12775/SPI.2020.2.005

Nadesłano: 27.03.2020 Zaakceptowano: 19.05.2020

Artykuły i rozprawy 
wskazały dwie główne tendencje: merytorycznq i formalnq. Pierwsza z nich dotyczy tematyki realizowanych zajęć z historii wychowania, druga natomiast wiqż̇e się ze zmianami ustawowo-organizacyinymi, które powoduja, że coraz mniej godzin przeznaczanych jest na zajęcia oraz zmianie ulega nazewnictwo tego przedmiotu. Dlatego tak ważna wydaje się refleksja nad rola edukacji historycznej w profilu kształcenia pedagogicznego - rozumiana nie tylko jako dostarczenie wiedzy, lecz także jako forma rozwoju i popularyzacji kultury pedagogicznej.

\section{ABSTRACT}

One of the subjects comprising the education of future educators is the history of education. Within the framework of the classes, the students are taught the issues of the Polish and general history of education, namely, pedagogical practice and the history of pedagogical thought. Not only are the achievements of general pedagogy and its sub-disciplines taken into account, but so are very important achievements of philosophy, sociology, or psychology, due to the interdisciplinary nature of pedagogy.

The article presents contemporary trends in the teaching of the history of education in selected academic institutions. The authors present a reflection on the significance of the history of education as a subject within pedagogical studies. In their analysis of syllabuses (curricula), they indicate two main tendencies: substantive and formal. The former concerns the subject matter of the classes conducted on the history of education, while the latter is connected with statutory and organizational changes which have led to fewer and fewer hours being allocated to this subject and the nomenclature of this course being changed. That is why it seems so important to reflect on the role of history education within pedagogical education, understood not only as providing knowledge, but also as a form of development and popularization of pedagogical culture.

\section{Wprowadzenie}

Jak powszechnie wiadomo, historia wychowania w programach kształcenia pedagogów pojawiła się dopiero w II połowie XIX wieku. Orędownikiem jej wprowadzenia był m.in. Ewaryst Estkowski, który pisał: 
Historia pedagogiki rozwija przed uczniem pewien rozumny plan, który $z$ niej tak wyraźnie przebija; ona napełnia go treścią, a tem samym sprawia, że później na posadzie nie będzie się oddawał marzeniom i próbom, które pedagogowie przed nim czynili, a których niepraktyczność, a może i śmieszność sama praktyka najwyraźniej wykazała (Estkowski 1849: 161).

\section{Dodawał również, że ten przedmiot}

[...] obudza samodzielność i ułatwia zrozumienie ujętych przez nauczyciela w system i uczniowi przedstawionych zasad pedagogicznych, które tenże za jej pomocą, jako wynik wielowiekowych spostrzeżeń, wraz z nauczycielem w sobie wyrabia i niejako do własnego przeświadczenia przybliża (Estkowski 1955: 45).

Tym samym Estkowski zainicjował refleksję nad znaczeniem historii wychowania w kształceniu nauczycieli. Wątek ten kontynuował nieco później Antoni Karbowiak w artykule pt. Uwagi o wartości, naszem znawstwie, i badaniu ojczystych dziejów nauczania $i$ wychowania (Karbowiak 1919: 473-479). Niewątpliwie był to czas formowania się historii wychowania w Polsce. Wówczas dyskutowano nad jej miejscem w naukach historycznych i pedagogicznych, celami i przedmiotem badań, jak również zadaniami badawczymi i dydaktycznymi, które powinna pełnić w przyszłości (Jakubiak 2000: 177-188). Należy również pamiętać o tym, że warunki rozwoju historii wychowania zmieniały się i były w dużej mierze zależne od sytuacji politycznej (Hellwig 2001: 77).

Historia wychowania jest jedną z subdyscyplin pedagogicznych oraz nauką o charakterze interdyscyplinarnym, gdyż leży na pograniczu historii i pedagogiki. Wykorzystuje źródła historyczne do odtwarzania przeszłości w aspekcie oświatowym. Przedmiotem zainteresowania historii wychowania są dzieje teorii pedagogicznej, a więc historia rozwoju myśli i doktryn pedagogicznych dotyczących sposobów ujmowania procesu wychowawczego, jak również dzieje praktyki pedagogicznej, stanowiące historię rozwoju placówek i instytucji wychowania. Rola edukacji historycznej w profilu kształcenia pedagogicznego polega nie tylko na dostarczaniu wiedzy, lecz także na kształceniu kultury pedagogicznej (Michalski 1985: 45). Ponadto jej zadaniem, w opinii Stanisława Michalskiego, jest wdrażanie słuchaczy do wartościowania zjawisk historyczno-pedagogicznych, a tym samym przyczynianie się do wnikliwego zrozumienia i realizowania 
przez nich współczesnych tendencji teorii i praktyki pedagogicznej, mając na uwadze doświadczenia z przeszłości.

W artykule analizie poddane zostały programy nauczania historii wychowania realizowane w kilku ośrodkach akademickich w Polsce, a mianowicie na Uniwersytecie Szczecińskim, Uniwersytecie Wrocławskim, Uniwersytecie Łódzkim, Uniwersytecie Warszawskim, Uniwersytecie im. Adama Mickiewicza w Poznaniu, Uniwersytecie w Białymstoku, Uniwersytecie Gdańskim, Uniwersytecie Warmińsko-Mazurskim w Olsztynie, Uniwersytecie Śląskim w Katowicach, w Akademii Pedagogiki Specjalnej im. Marii Grzegorzewskiej w Warszawie, a także na Uniwersytecie Mikołaja Kopernika w Toruniu. Uwzględniono również publikacje autorów prezentujące specyfikę nauczania tego przedmiotu w kształceniu akademickim (Mokrzecki 2000; Gumuła, Majewski 2005; Szulakiewicz 2007; Falkowska 2017: 49-64; Falkowska, Grabowska-Pieńkosz 2018). $\mathrm{Na}$ podstawie pozyskanych materiałów wyodrębnione zostały dwie główne tendencje w nauczaniu tego przedmiotu, a mianowicie merytoryczna i formalna. Pierwsza $z$ nich dotyczy tematyki realizowanych zajęć $\mathrm{z}$ historii wychowania, druga natomiast wiąże się ze zmianami ustawowo-organizacyjnymi, które powodują, że coraz mniej godzin przeznaczanych jest na zajęcia oraz zmianie ulega nazewnictwo tego przedmiotu.

\section{Tendencje merytoryczne w nauczaniu historii wychowania}

Jak już wspomniano, jednym z ważnych przedmiotów w kształceniu przyszłych pedagogów jest historia wychowania. Jej zadaniem, jak stwierdził Stanisław Kot,

[...] jest badanie, jak w poszczególnych stadiach swego rozwoju różne społeczeństwa organizowały u siebie wychowanie i dlaczego takie właśnie, a nie inne stosowały systemy pedagogiczne. Trzeba wiec doszukać się związku miedzy stanem społeczeństwa, jego urządzeniami społecznymi, politycznymi, gospodarczymi, jego pojęciami moralnymi i umysłowymi a ideałem wychowawczym, praktyką i teorią pedagogiczną. Sam opis tej praktyki i teorii bez uchwycenia związku z życiem nie jest wystarczający, gdyż nie odsłania istotnych sprężyn pracy wychowawczej. Dopiero gdy się ustali tę zależność, okaże się, że sposób wychowania w każdej epoce stanowi pewna uzasadniona całość, że wszystkie jego szczegóły zdążają do pewnego celu, słowem odkryje się system pedagogiczny epoki (Kot 2010: 21). 
W ramach realizacji zajęć przekazywane są zagadnienia z zakresu polskiej i powszechnej historii wychowania, a mianowicie praktyki pedagogicznej i historii myśli pedagogicznej. Uwzględniany jest nie tylko dorobek pedagogiki ogólnej i jej subdyscyplin, lecz także ze względu na interdyscyplinarny charakter pedagogiki również bardzo ważny jest dorobek filozofii, socjologii, psychologii. Na podstawie analizy programów $\mathrm{z}$ historii wychowania realizowanych na wykładach, ćwiczeniach, konwersatoriach w wybranych ośrodkach akademickich można stwierdzić, że treści z tego przedmiotu realizowane są w sposób chronologiczny, przy jednoczesnym podkreśleniu znaczenia wybranych wydarzeń w innych obszarach życia społecznego, szczególnie w szeroko rozumianej działalności społeczno-oświatowej. Proponowana tematyka nawiązuje zarówno do teorii, jak i praktyki pedagogicznej. Zasadniczo można wyróżnić kilka głównych tendencji w nauczaniu historii wychowania. Po pierwsze, w kształceniu historycznym kładzie się nacisk na przybliżenie koncepcji pedagogicznych, które miały znaczący wpływ na rozwój pedagogiki i powstanie jej subdyscyplin. W szczególności wiele miejsca poświęca się na zapoznanie studentów $\mathrm{z}$ osiągnięciami przedstawicieli europejskiej i polskiej myśli pedagogicznej, wykorzystując w tym zakresie dorobek nie tylko pedagogiki, ale też psychologii, filozofii i socjologii. Druga tendencja dotyczy przekazywania wiedzy na temat reform oświatowych wprowadzanych w Polsce i w państwach europejskich na przestrzeni dziejów. Po trzecie, studenci zapoznawani są z działalnością różnych szkół, instytucji, organów, organizacji społeczno-oświatowych, które miały wpływ na funkcjonowanie oświaty. Jako czwartą tendencję można wymienić kwestie dotyczące ideału wychowania i jego zmian, jakie pojawiały się w poszczególnych epokach. Przejdźmy do przybliżenia treści z zakresu historii wychowania charakterystycznych dla tych tendencji.

Odnosząc się do pierwszej tendencji, należy wskazać, że studenci podczas realizacji zajęć z historii wychowania poznają koncepcje pedagogiczne m.in.Jana Jakuba Rousseau - twórcy wychowania naturalnego, Jana Henryka Pestalozziego - prekursora podstaw pedagogiki socjalnej i opiekuńczo-wychowawczej, Fryderyka Froebela - pioniera w zakresie wychowania przedszkolnego, Jana Fryderyka Herbarta - ojca pedagogiki naukowej, przedstawicieli koncepcji „Nowego Wychowania”: Johna Deweya, Marii Montessori czy Ellen Key. 
Zdobywają wiadomości również o prekursorach polskiej pedeutologii: Andrzeju Fryczu Modrzewskim, Grzegorzu Piramowiczu, Janie Władysławie Dawidzie. Podczas realizacji programu przekazywana jest też wiedza na temat koncepcji poświęconych nauczaniu początkowemu wypracowanych przez Ewarysta Estkowskiego, Adolfa Diesterwega, a także o znaczeniu dzieła Marii Grzegorzewskiej w rozwoju teorii i praktyki kształcenia specjalnego oraz o zasługach Heleny Radlińskiej w zakresie pedagogiki społecznej. Poznają również poglądy zwolenników dwóch ideologii wychowawczych w okresie II Rzeczypospolitej, czyli wychowania narodowego (Stanisław Prus-Szczepanowski, Zygmunt Balicki, Lucjan Zarzecki) oraz wychowania państwowego (Sławomir Czerwiński czy Kazimierz Sośnicki).

Wśród realizowanych tendencji $\mathrm{w}$ programie kształcenia historycznego uwzględniane są także zagadnienia dotyczące reform oświatowych. Studenci zdobywają wiadomości na temat reform przeprowadzonych przez Komisję Edukacji Narodowej (1773-1794), reform wprowadzanych w XIX wieku na terenie zaboru pruskiego i rosyjskiego, pracach podjętych przez Radę Szkolną Krajową (1867-1921) na rzecz zmian w edukacji i szkolnictwa. Omawiane są również okoliczności i skutki wprowadzonych ustaw w okresie II Rzeczypospolitej m.in. $z$ lat 1919, 1920, 1926, 1932, 1933, które regulowały funkcjonowanie polskiego szkolnictwa powszechnego, średniego, kształcenia nauczycieli, szkolnictwa zawodowego czy szkolnictwa wyższego. Ponadto $\mathrm{w}$ realizowanych treściach uwzględniane są reformy oświatowe z okresu Polskiej Rzeczypospolitej Ludowej, wynikające z układu geopolitycznego oraz ustaleń zjazdów oświatowych, zgodnych z oczekiwaniami bloku partyjnego. Studentom przekazywane są również informacje o zmianach, jakie pojawiły się w polskiej oświacie po 1989 roku, aż po czasy współczesne, a mianowicie założenia i realizacja wprowadzonych ustaw w latach: 1991, 1999, 2005, 2017, 2018 odnoszących się do wszystkich typów i poziomów polskiego szkolnictwa. Z kolei znajomość reform oświatowych i okoliczności ich wprowadzania mogą pomóc studentom w zrozumieniu i ocenie aktualnych wydarzeń i zmian, jakie pojawiły się w tej dziedzinie życia publicznego.

W ramach historii wychowania prezentowane są też treści dotyczące działalności szkól, instytucji, znaczących organizacji w dziejach polskiej i europejskiej oświaty. Studenci zdobywają wiedzę na temat 
szkół, począwszy od tych, które działały przy kościołach (parafialnych, klasztornych, katedralnych, kolegiackich) oraz były prowadzone przez zakony (jezuici, pijarzy, oratorianie), poprzez szkoły różnowiercze w Polsce (luterańskie, kalwińskie, ariańskie), szkolnictwo rycerskie aż po współczesny rozwój szkolnictwa publicznego i prywatnego na różnych poziomach kształcenia. Omawiana jest również działalność organów, które podjęły się wprowadzenia ważnych zmian w polskiej oświacie: m.in. Komisji Edukacji Narodowej, Izby Edukacyjnej, Rady Szkolnej Krajowej, Ministerstwa Wyznań Religijnych i Oświecenia Publicznego, a także po II wojnie światowej Ministerstwa Oświaty, Ministerstwa Oświaty i Szkolnictwa Wyższego, Ministerstwa Oświaty i Wychowania czy Ministerstwa Edukacji Narodowej.

$\mathrm{W}$ programie zajęć realizowane są też zagadnienia dotyczące działalności instytucji, organizacji zasłużonych na rzecz opieki nad osobami niepełnosprawnymi, ubogimi, żebrakami, podrzutkami oraz dziećmi i młodzieżą zaniedbaną, wykolejoną, nieprzestrzegającą ogólnego porządku normatywnego. Studenci poznają funkcjonowanie różnych placówek oraz organizacji wspierających nauczycieli i zasłużonych w dziele reformowania oświaty, m.in.: Towarzystwa do Ksiąg Elementarnych, Towarzystwa Pedagogicznego, Towarzystwa Nauczycieli Szkół Wyższych, Tajnej Organizacji Nauczycielskiej czy Związku Nauczycielstwa Polskiego.

Ostatnia $\mathrm{z}$ wymienionych tendencji w nauczaniu historii wychowania dotyczy ideału wychowania, czyli najważniejszego celu w wychowaniu człowieka, którego cechy uwarunkowane są tradycją kulturową, potrzebami społecznymi oraz panującą ideologią. Studenci zapoznawani są z ideałami, które pojawiały się na przestrzeni dziejów, począwszy od czasów najdawniejszych, czyli antyku (ideał wychowania spartańskiego), średniowiecza (ideał wychowania rycerskiego), przez czasy nowożytne (ideał wychowania humanistycznego), ideał dobrego i oświeconego obywatela wypracowany przez KEN, rozwijany przez polską inteligencję w XIX wieku. Ideałem aż po wiek XVIII miał być dobry katolik, rycerz-żołnierz, miłujący wolność i hołdujący republikańskim tradycjom. Natomiast na przełomie XIX i XX wieku dominował ideał wychowania narodowego, a po 1926 roku ideał państwowca. Znaczące zmiany pojawiły się po 1945 roku, kiedy zaczęto wdrażać idee komunistyczne w obrębie oświaty i wychowania, a tym samym pożądany przez władze PRL był ideał oparty na 
założeniach ideologii marksistowsko-leninowskiej. Natomiast dopiero od 1989 roku nastąpiły demokratyczne zmiany w polskim systemie wychowania, co również miało bezpośrednie znaczenie w tworzeniu ideału wychowania.

W realizacji wymienionych treści programowych niezwykle ważne są publikacje historyków wychowania, nie tylko te klasyczne, czyli podręczniki autorstwa np. Stanisław Kota czy Łukasza Kurdybachy, ale także najnowsze prace napisane przez kolejne pokolenie historyków wychowania, które doskonale uzupełniają dotychczas niezbadane obszary. W realizacji treści historycznych tradycyjnie pomocne są również teksty źródłowe, które rozwijają umiejętności związane z czytaniem i odbiorem zawartych $w$ nich informacji na poziomie dosłownym, przenośnym i symbolicznym. Stwarzają one możliwość rozwoju samodzielnego myślenia, krytycyzmu, rozwiązywania zadań, dokonywania analizy wydarzeń na tle zjawisk oświatowych, społecznych, kulturowych, odróżniania faktów od opinii, prawdy od fikcji. Przypisuje się im różne role i funkcje. Proponowane w ramach zajęć materiały źródłowe mają na celu wzbogacić i pogłębić zdobyte przez studentów wiadomości czy potwierdzić te uzyskane dzięki innym źródłom. Teksty te ilustrują i dokumentują różnorodne problemy z dziejów oświaty i wychowania na przestrzeni dziejów. Poza tym umożliwiają studentom lepsze zrozumienie zdarzeń z przeszłości. Pozwalają też na upoglądowienie i uatrakcyjnienie przebiegu zajęć dydaktycznych. Jednak, ze względu na zmniejszającą się liczbę godzin przeznaczonych na realizację programu $z$ historii wychowania, nie ma możliwości zapoznawania się z treściami źródeł i ich szczegółowej analizy podczas zajęć. Dlatego można stwierdzić, że współcześnie mają one głównie cel dokształcający i samokształceniowy.

Trzeba zaznaczyć, że zajęcia $z$ historii wychowania nie ograniczają się wyłącznie do biernego przyswajania przez studentów dat czy poszczególnych wydarzeń, lecz kładzie się nacisk na osadzenie omawianych treści w szerszym kontekście, uwzględniając czynniki społeczne, ekonomiczne czy kulturowe. Jak podkreślał Emil Durkheim, francuski filozof, socjolog i pedagog, zwolennik oparcia kultury pedagogicznej na szerokich podstawach historycznych, ideał pedagogiczny poszczególnych epok odzwierciedla aktualny stan społeczeństwa. Dlatego istota studiowania historii wychowania nie polega na tworzeniu od nowa różnych systemów czy koncepcji 
pedagogicznych, ale istotne jest poznanie oraz zrozumienie osiągnięć różnych osób i docenienie ich prac oraz zainicjowanych przez nich zmian na przestrzeni dziejów. Niezwykle ważne jest docenienie pracy i starań poszczególnych ludzi czy całych zbiorowości, poznanie procesu ewaluacji, jaki dokonał się w przeszłości, uwzględniając okoliczności sprzyjające czy też zakłócające przebieg danych procesów i zjawisk mających miejsce w przeszłości.

Warto nadmienić, że realizowany w toku studiów pedagogicznych program $z$ historii wychowania daje podwaliny studentom i ułatwia zgłębianie wiedzy z innych subdyscyplin pedagogicznych, głównie pedagogiki ogólnej, pedagogiki przedszkolnej i wczesnoszkolnej, dydaktyki, teorii wychowania, pedagogiki społecznej, pedagogiki opiekuńczo-wychowawczej czy pedagogiki specjalnej. Dlatego tematyka historii wychowania zazwyczaj realizowana w formie wykładów, ćwiczeń i własnej pracy studentów, ma na celu przygotowanie ich do zdobywania i poszerzania wiedzy na dalszych etapach studiów, a w konsekwencji do świadomej pracy zawodowej.

\section{Tendencje formalne w nauczaniu zagadnień historycznych}

Zagadnienia $\mathrm{z}$ historii wychowania są realizowane na studiach pedagogicznych $\mathrm{w}$ ramach przedmiotów o różnym nazewnictwie. Zazwyczaj w analizowanych ośrodkach akademickich na kierunkach pedagogika ogólna, pedagogika przedszkolna i wczesnoszkolna stosowana jest klasyczna nazwa, czyli Historia wychowania, ale pojawiają się również takie określenia jak: Historia oświaty i wychowania, Historia myśli pedagogicznej czy Historia wychowania i myśli pedagogicznej. Ze względu na rozwój nauk o wychowaniu, a tym samym rozszerzanie oferty kształcenia pedagogicznego, zagadnienia historyczne realizowane są także na kierunku Pedagogika specjalna. Są to następujące przedmioty: Historia pedagogiki specjalnej, Rys historyczny niepełnosprawności, Historia kształcenia specjalnego, Pionierzy kształcenia specjalnego w dziejach, Historia niepełnosprawności. Przedmiot Historia pedagogiki specjalnej nawiązuje do przedmiotu Historia wychowania i ma za zadanie przybliżyć historię poszczególnych subdyscyplin pedagogiki specjalnej. Studenci poznają także zagadnienia dotyczące kształcenia nauczycieli dla szkół specjalnych oraz przedstawicieli poszczególnych jej subdyscyplin. Z kolei zadaniem 
przedmiotu Rys historyczny niepełnosprawności jest prezentacja miejsca osób z niepełnosprawnościami w społeczeństwach kolejnych epok historycznych. Historia kształcenia specjalnego ma na celu ukazanie historii kształcenia dzieci i młodzieży niedostosowanej społecznie, niewidomej i słabowidzącej, niesłyszącej i słabosłyszącej, osób niepełnosprawnych intelektualnie, wybitnie zdolnych, przewlekle chorych i kalekich. Z kolei przedmiot Pionierzy kształcenia specjalnego w dziejach prezentuje sylwetki prekursorów szkolnictwa specjalnego, ich dorobek naukowy, wkład w powstanie i rozwój placówek oświatowych na tle wydarzeń historycznych. Historia niepełnosprawności ma za zadanie przybliżyć problematykę wychowania i kształcenia osób z niepełnosprawnością na przestrzeni dziejów, jak również sylwetki prekursorów badań nad niepełnosprawnością w Polsce i Europie. To tylko niektóre przykłady usamodzielniania się dziejów pedagogiki specjalnej. Można powiedzieć, że mamy do czynienia $\mathrm{z}$ wyraźną tendencją w nauczaniu historii wychowania, jaką jest wyodrębnianie historii pedagogiki specjalnej w kształceniu pedagogów.

$\mathrm{Na}$ podstawie dokonanych analiz proponowanych przez wybrane ośrodki akademickie przedmiotów, trzeba stwierdzić, że na kierunkach pedagogicznych przygotowujących nauczycieli do pracy zawodowej od kilku lat można zaobserwować działania polegające na znacznym zmniejszeniu liczby godzin przeznaczonych na realizację treści z zakresu historii wychowania. Zazwyczaj na wymienione przedmioty w programach kształcenia przeznacza się od 60 (wykłady i ćwiczenia) do 15 godzin dydaktycznych, czasami realizowanych wyłącznie w formie wykładu. W przypadku tak znaczącego ograniczenia czasowego często niemożliwe jest zaprezentowanie wszystkich treści z zakresu historii wychowania czy historii pedagogiki specjalnej. Trzeba również zauważyć, że w opisach tych przedmiotów prowadzący wyraźnie wskazują na umiejętności wykorzystania zdobytej podczas zajęć wiedzy w praktyce. Akcentują to, że student potrafi wykorzystywać interdyscyplinarną wiedzę teoretyczną w celu identyfikowania oraz interpretowania złożonych i nietypowych problemów związanych $\mathrm{z}$ wychowaniem, kształceniem i opieką w różnych okresach historycznych.

W wyniku zmniejszania liczby godzin dydaktycznych przeznaczonych na realizację programu $\mathrm{z}$ historii wychowania środowisko historyków wychowania podejmuje próby włączania zagadnień 
historycznych na różnych poziomach kształcenia akademickiego przyszłych pedagogów. Wówczas treści historyczne proponuje się studentom i doktorantom (studenci studiów I, II i III stopnia) w ramach takich przedmiotów jak: Historia opieki, Historia opieki i wychowania (wybrane koncepcje opieki i wychowania na przestrzeni dziejów, tradycja kształtowania się systemów opiekuńczo-wychowawczych w Polsce i na świecie), Pedeutologia (analiza i interpretacja wybranych koncepcji pedeutologicznych oraz ich autorów na przestrzeni XIX i XX wieku w Polsce). Ponadto przez historyków wychowania prowadzone są przedmioty: Badania historyczne w pedagogice, Metodologia badań historyczno-pedagogicznych (specyfika badań historycznych prowadzonych w naukach pedagogicznych, w szczególności poszukiwanie, interpretacja i wartościowanie informacji zawartych w źródłach historycznych), Badania biograficzne w pedagogice (znaczenie interdyscyplinarnego podejścia do problematyki badań biograficznych $\mathrm{w}$ naukach pedagogicznych). Studenci uczestniczą również w takich zajęciach jak: Twórcy polskiej myśli pedagogicznej (najwybitniejsi twórcy polskiej myśli pedagogicznej w poszczególnych epokach historycznych ze stworzonymi przez nich koncepcjami), Dawne zabawy i zabawki dziecięce, Zabawy i zabawki w edukacji dzieci (zagadnienia związane ze znaczeniem zabaw i zabawek w życiu dziecka na różnych etapach jego rozwoju, uwzględniając osiągnięcia polskich, europejskich pedagogów i działaczy społeczno-oświatowych). To tylko niektóre przykłady przedmiotów, w ramach których realizowane są zagadnienia historyczne w kształceniu przyszłych pedagogów.

Warto wspomnieć, że już od połowy lat 90 . XX wieku można zaobserwować zjawisko związane $\mathrm{z}$ ograniczaniem i eliminowaniem treści historycznych na kierunkach pedagogicznych. Karol Poznański, wybitny historyk wychowania, już wówczas zadał bardzo ważne pytanie: „Czy można budować szeroko pojmowaną kulturę pedagogiczną bez znajomości polskich tradycji oświatowych i europejskiego dorobku oświaty i wychowania?” Odwołując się do doświadczeń praktyki akademickiej, stwierdził zarazem, że niemal całe studia pedagogiczne „mają piętno ahistoryczności” (Poznański 1995: 41). Jest to sytuacja paradoksalna, ponieważ wyraźnie widoczny jest rozwój nauk o wychowaniu oraz rozszerzanie oferty programowej dla przyszłych pedagogów. 
Trzeba przy tym zaznaczyć, że wiedza historyczna, nawet w elementarnym wymiarze, jest potrzebna nie tylko pedagogom, ale również studentom na specjalnościach nauczycielskich takich jak fizyka, biologia czy filologia (Majewski 2002: 50). Systematyczne ograniczanie, a nawet eliminowanie treści historycznych w programach kształcenia pedagogicznego pozbawia studentów ważnego zaplecza, do którego odwołują się przedstawiciele innych dyscyplin pedagogicznych. Hanna Pohoska jeszcze przed II wojną światową zauważyła, że

Przeciwnicy „historyzmu” w kształceniu pedagogicznym nauczyciela pragną, by wiedza pedagogiczna budowana była in abstracto, w oderwaniu od zjawisk życiowych. Nie orientują się oni w tym, że zerwanie z tradycją historyczną jest w tym wypadku zerwaniem związku ze współczesnością, bo rzuca teorie pedagogiczne i dociekania psychologiczne na tło abstrakcji (Pohoska 1935: 10-11).

Poza tym należy się zgodzić ze słowami Jerzego Topolskiego, który w książce pt. Świat bez historii postawił bardzo ważną tezę, że „myślenie historyczne jest składnikiem kultury, bez którego nie byłoby możliwe konstruowanie programów działania i aktywny stosunek do zastanej rzeczywistości pozostaje bez zmiany" (Topolski 1998: 33). Dlatego współczesny nauczyciel powinien być świadomy dorobku państwa polskiego w zakresie oświaty, jak i jego wkładu w kulturę europejską. Jako przykład można podać utworzenie Akademii Krakowskiej, która po uniwersytecie praskim była pierwszą wyższą uczelnią w Europie Środkowo-Wschodniej. Z kolei dorobek Komisji Edukacji Narodowej, pierwszego w dziejach Europy ministerstwa oświaty, był wzorem dla innych państw europejskich w procesie reformowania systemu szkolnego. Także dzisiaj działalność KEN jest wzorem dokonań w obszarze oświaty na skalę europejską. Warto też wspomnieć, że koncepcja „Nowego Wychowania” spowodowała pewnego rodzaju odnowę szkoły, treści i metod dydaktyczno-wychowawczych, stawiając w centrum oddziaływań wychowawczych dziecko i jego potrzeby. To jedynie wybrane elementy w programie kształcenia pedagogów, których prezentacja jest pomocna nie tylko w zakresie opisywania minionej rzeczywistości edukacyjnej, ale przede wszystkim podczas wyjaśniania i wartościowania zdarzeń z przeszłości. Niewątpliwie, należy zauważyć, że znajomość historii wychowania jest ważna w procesie budowania tożsamości nauczycieli. 


\section{Uwagi końcowe}

Podsumowując, można stwierdzić, że historia wychowania jest jedną z ważniejszych subdyscyplin pedagogicznych, ponieważ dzięki niej studenci poznają prekursorów, zasłużonych działaczy, którzy mieli zasadniczy wpływ na powstanie i rozwój subdyscyplin pedagogicznych, m.in. pedagogiki przedszkolnej, pedagogiki wczesnoszkolnej, pedagogiki społecznej, pedagogiki opiekuńczo-wychowawczej. Wśród studentów kształtowana jest świadomość zachodzących procesów i warunków, w jakich przebiegało wychowanie człowieka w różnych epokach i kręgach kulturowych. Mają oni również możliwość poznania czynników wpływających na rozwój nauk czy kształtowanie się prądów umysłowych i moralno-religijnych. Znajomość historii pozwala obiektywnie ocenić udział różnych narodów w rozwoju wiedzy i praktyki pedagogicznej oraz zjawisk wychowawczych i ich wpływ na człowieka na przestrzeni dziejów. Wszystko to ma na celu logiczne uzasadnianie przekazywanych treści, łączenie ich w pewne strukturalne całości, co umożliwia szersze spojrzenie na realizowane programy studiów pedagogicznych, a także zapewnia pogłębianie i poszerzanie przekazywanych treści na dalszych etapach studiów. Taka postawa korzystnie wpływa na myślenie strukturalne, ponieważ pozwala łączyć dotychczasową wiedzę z nowymi wiadomościami, a to z kolei przyczynia się do poszerzania kultury umysłowej.

Warto też zauważyć, że przed historykami wychowania stoi trudne zadanie związane z postępującym procesem „odhistorycznienia” programów realizowanych na kierunkach pedagogicznych. Historia wychowania jest przecież jedynym przedmiotem $\mathrm{w}$ toku studiów, który zagadnienia związane $\mathrm{z}$ wychowaniem pokazuje $\mathrm{w}$ szerokim kontekście, uwzględniając aspekty społeczne, kulturowe, ekonomiczne czy moralno-religijne. Tym samym dobór realizowanych w toku zajęć treści uświadamia studentom, jak trudna jest sztuka wychowania i od jak wielu czynników zależy. Dlatego nie należy wysuwać pochopnych wniosków wobec pracy pedagogicznej, a wykonując ten zawód trzeba być ostrożnym w doborze środków i metod dydaktyczno-wychowawczych. Studenci podczas zajęć z tego przedmiotu poznają tradycję i wypracowany na przestrzeni wieków dorobek nauk o wychowaniu, okoliczności rozwoju oświaty i wychowania czy 
pozycję, jaką Polska zajmowała w dziejach teorii i praktyki edukacyjnej w Europie. Warto nadmienić, że historia wychowania bazując na doświadczeniach pedagogicznych, które miały miejsce w przeszłości, integruje pozostałe dyscypliny pedagogiczne.

Mając na uwadze powyższe ustalenia, warto również przywołać opinię Juliana Dybca, który podkreśla:

Każde kształcenie, zwłaszcza pedagogiczne, którym się zajmujemy winno mieć wizje, koncepcje absolwenta, człowieka którego chce tworzyć. [...] Najogólniej stwierdzić należy, że powinien rozumieć świat, studia winny mu także ułatwić zrozumienie siebie, wyuczyć pracy nad własnym charakterem, o czym nieustannie się zapomina. Powinien zdobyć również zrozumienie innych, zwłaszcza swych późniejszych podopiecznych - szczególnie młodych uczniów. Studia pedagogiczne powinny wyrabiać mądrość o świecie, o człowieku (Dybiec 2012:3).

Bez wiedzy z zakresu historii wychowania zadanie to może się okazać trudne do zrealizowania.

\section{Bibliografia}

Dybiec J. (2012). Historia wychowania wobec wyzwań wspótczesnych czasów i nowych „Standardów ksztatcenia" na studiach pedagogicznych, [w:] E. Kula, M. Pękowska (red.), Historia wychowania. Przewodnik programowy dla studentów Wydziatu Pedagogicznego i Artystycznego Uniwersytetu Jana Kochanowskiego w Kielcach, Kielce, s. 13-29, https://www.ujk. edu.pl/strony/Ewa.Kula/pliki/przewodnik_hw_2013.pdf.

Estkowski E. (1849). Czy potrzeba uczyć historii pedagogiki po seminariach?, „Szkoła Polska”, t. 1, z. 3, s. 154-171.

Estkowski E. (1955). Wybór pism pedagogicznych, opracował i wstępem poprzedził M. Szulkin, Warszawa: Państwowe Zakłady Wydawnictw Szkolnych.

Falkowska J. (2017). Historia wychowania w Uniwersytecie Mikotaja Kopernika w latach 2000-2015. Instytucjonalizacja - badanie - nauczanie, [w:] T. Gumuła (red.), Historia wychowania na przetomie XX i XXI wieku, Kielce: Kieleckie Towarzystwo Naukowe, s. 49-64.

Falkowska J., Grabowska-Pieńkosz D. (2018). Historia wychowania na Uniwersytecie Mikotaja Kopernika, Toruń: Fundacja Societas et Ius.

Gumuła T., Majewski S. (red.) (2005). Historia wychowania w ksztatceniu nauczycieli. Tradycja i wspótczesność, teoria i praktyka, Kielce: Wydawnictwo Akademii Świętokrzyskiej im. Jana Kochanowskiego.

Hellwig J. (2001). Dzieje historii wychowania w Polsce i jej twórcy. Próba zarysu bistorycznego, Poznań: Eruditus. 
Jakubiak K. (2000). Ksztaltowanie podstaw metodologicznych i dydaktycznych historii wychowania w II Rzeczypospolitej, „Rozprawy z Dziejów Oświaty", t. 40, s. 144-188.

Karbowiak A. (1919). Uwagi o wartości, naszem znawstwie i badaniu ojczystych dziejów nauczania i wychowania, „Nauka Polska, jej potrzeby, organizacja i rozwój", t. 2, s. 473-479.

Kot S. (2000). Historia wychowania. Zarys podręcznikowy, t. 1: Od starożytnej Grecji do potowy wieku XVIII, Warszawa: Wydawnictwo Akademickie „Żak".

Majewski S. (2002). Znaczenie historii wychowania pedagogicznym ksztatceniu nauczycieli, [w:] T. Gumuła (red.), Nabywanie kompetencji nauczycielskich w toku studiów wyższych, Kielce: Wydawnictwo Akademii Świętokrzyskiej im. Jana Kochanowskiego, s. 45-51.

Michalski S. (1985). Rola historii wychowania w procesie ksztatcenia i dokształcania nauczycieli, „Zeszyty Naukowe Wyższej Szkoły Pedagogicznej w Bydgoszczy. Studia Pedagogiczne”, t. 13, s. 45-60.

Mokrzecki L. (2000). Historia wychowania w Gdansku z perspektywy pięcdziesięciolecia (1946-1996), Gdańsk: Wydawnictwo Uniwersytetu Gdańskiego.

Pohoska H. (1935). Rola bistorji wychowania w ksztatceniu nauczycieli, „Wiadomości Historyczno-Dydaktyczne", nr 1-2, s. 9-14.

Poznański K. (1995). Historia wychowania. Stan obecny i perspektywy rozwoju, „Rocznik Pedagogiczny”, t. 18, s. 39-54.

Szulakiewicz W. (2007). Historia wychowania w Uniwersytecie im. Adama Mickierwicza, Warszawa: Studio Wydawnicze Familia.

Topolski J. (1998). Świat bez historii, Poznań: Wydawnictwo Poznańskie.

\title{
ADRESY DO KORESPONDENCJI
}

\author{
Dr Dorota Grabowska-Pieńkosz \\ Uniwersytet Mikołaja Kopernika w Toruniu \\ Wydział Filozofii i Nauk Społecznych \\ Instytut Nauk Pedagogicznych \\ e-mail: dogra@umk.pl \\ Dr hab. Joanna Falkowska, prof. UMK \\ Uniwersytet Mikołaja Kopernika w Toruniu \\ Wydział Filozofii i Nauk Społecznych \\ Instytut Nauk Pedagogicznych \\ e-mail: jfal@umk.pl
}

